\title{
The Effect Of Repetition Sprint Training Method Combined With The Level Of Physical Fitness Toward The Speed Of 100 Meter Run
}

\author{
Luh Putu Tuti Ariani \\ The Faculty Of Sport And Health, Ganesha University Of Education, Indonesia \\ *Corresponding author E-mail: tuti.ariani@undiksha.ac.id
}

Manuscript received 15 April 2021; revised 1 May 2021; accepted 15 June 2021. Date of publication 3 July 2021

\begin{abstract}
There are various modern training methods to increase achievement in a 100-meter run. This research used the repetition sprint method. This research aims to find out the effect of the repetition sprint method on the students with high physical fitness towards the speed in the 100 -meter run. The method used in this research is the pre-test post-test design. The sample of this research was 15 students of the Sports Training Education Study Program, sport and health faculty of the Ganesha University of Education. These students are those with the highest physical fitness among 90 students in total. The physical fitness test was through a 2.4-kilometer run. The repetition sprint method was applied in 24 meetings, started with a pre-test and ended with a post-test. The data were analyzed by using descriptive statistics and paired sample T-test. The result shows that there is a difference found before and after the training. It is found that there is a 1.15 -second increase in the average speed of the 100-meter run from the whole 15 samples. Therefore, it can be concluded that the repetition sprint training method increases the speed in the 100-meter run.
\end{abstract}

Keywords: Repetition sprint, physical fitness, the 100-meter run achievement.

\section{Introduction}

Republik Indonesia's Law number 3 year 2005 on the National Sport System states that national sports training and development should ensure equal access to sports, increase health and fitness, improve achievement and sport management to face the challenge and demand in national and global level. This sport system shows the government's support to hold the right sports training and development program for the society. Sports has become the need for Indonesian people. It has been done for various purposes such as having quality free time, recreation, health, prestige, and gaining achievement. Gaining achievement has become one of the most important purposes in doing sports. It becomes the benchmark of sport development and establishment. An athlete's success in gaining achievement is determined by congenital and environmental factors.

Achievement is defined as the result of an effort. Someone will gain an achievement as the result of his effort [1]. The sport achievement management is done in planned, staged and on a continuous and sustainable basis. One of the important factors in determining the sucess i sport achievement is choosing the right training method. Through a purposeful program, an athlete's talent will be well trainned so he/ she can gain golden achievement in sport.

The 100-meter sprint run has become the most popular competition in athletic port. Its world champion athletes are the fastest people in the world. Indonesia's representative, Lalu Muhammad Zohri, won the world athletic championship held in Finland in 2018. The 20-yearold reached the finish line in 10.18 seconds. It shows that the sport achievement management in Indonesia has done well compared to the other countries in the world.

This fact has proven that through the correct training method and a set of purposeful programs, Indonesia has the power to raise the fastest men in the world. Several factors contribute to improving the achievement in the 100-meter run, such as the speed of muscular contraction, the speed of endurance, and power coordination [2]. It is a type of sport that requires running skills on a short track in a short time. Therefore the training program should be composed carefully by involving the clear expected target. It should be formulated according to the main characteristic of sprint run.

The physical training program gives such a positive response toward the athlete body. It improves the neurophysiology condition and helps to adjust the development of body tissues [3]. Intensive physical training is beneficial to maintain the athlete's condition. Several concerns have to be taken to improve the physical condition, especially speed, such as regular training, correct training method, and training on specific muscles to improve speed. 
This research uses the repetition sprint method. This method helps to improve the speed with a positive reaction. Physical fitness also gives a major impact on improving an athlete's achievement. A person with good physical fitness can reach better live quality, as the body resists tiredness better. Physical fitness is defined as the body's ability to deal with a complex daily activity on a relatively long duration, without causing excess tiredness. Physical fitness has become an indicator of knowing society's health. According to [4], physical activities, such as sport, involves physical fitness aspects as the basic movement or physical activities of the human's body. Without physical fitness aspects, physical activities, especially sports, will not be able to reach the utmost result. An athlete with good fitness has a proportional body, strong bones, elastic joints as well as strong muscles [3]. Better fitness is gained through quality physical activities. There are several basic principles in physical exercises to build and maintain fitness, as stated by [3], such as individual, adaptation, excessive loads, progressive loads, specification, variation, warming up and cooling down steps, periodization, opposite, moderate loads, and systemic training. To reach the goals of the training, the form of exercises should be chosen accordingly to its principles to give a maximum impact when it is done together with the right amount of exercises. Physical fitness is also essential to every individual for better life quality and avoids overtiredness in everyday activities. The background explanation triggered the writer to find the effect of the repetition sprint training method on the students with high physical fitness towards their ability in the 100-meter run. It is expected that physical fitness can be involved as the attribute variable to the characteristics of the 100-meter run to improve achievement in running.

\section{Literature Review}

\subsection{Physical fitness}

Physical fitness is an absolute requirement to achieve a quality life. So physical fitness needs to be nurtured and developed with a healthy lifestyle and exercising regularly. The condition of a person's physical fitness who is able to adapt to all physical and psychological burdens received is the basis for achieving optimal productivity / work performance. Based on special functions, physical fitness can be divided into three groups, namely: groups based on occupation, groups based on circumstances, and groups based on age. One of the functions of the group based on work is students / learners. Students are members of society who try to develop their potential through the learning process available at certain pathways, levels, and types of education.

Dynamic health, namely being healthy in a state of movement, becomes a person's basic physical ability to be able to carry out the tasks that must be done. Therefore, it is necessary to develop and maintain one's physical fitness, which is a person's dynamic healthy degree. Physical fitness is a state of physical ability that can adjust the functions of the body's organs to certain physical tasks and / or to environmental conditions that must be handled in an efficient manner, without excessive fatigue and have fully recovered before the assignment arrives. the same the next day. The concept of physical fitness is differentiated between fitness related to health and fitness related to performance. The physical condition of an athlete is good, so the athlete will be able to learn well as expected. If the athlete experiences fatigue, it will be able to affect the athlete's learning motivation so that the athlete will not be able to train properly following the training given by the coach. Physical fitness plays an important role in life, by having a good level of physical fitness will certainly have high productivity and can work effectively and efficiently.

\subsection{Repetition Sprints}

Sprint 100 meter skill is an ability that is characterized by the process of moving body position from one place to another quckly [5]. Sprinting is essential to success in many sports and many different training methods have been used to improve sprinting performance [6] . Free sprint training, or sprint training without the use of any external equipment, form the basis for most speed training programs [7]. Before repetitions (repetitions) are carried out, it is necessary to recover the origin long enough, this is especially important to increase anaerobic power and oxygen-dept. Recovering from a rest period in a repetition sprint exercise usually uses jogging or walking activities. The activity profiles of team sports necessitate the development of power, acceleration, speed and the ability to perform repeated high intensity runs and sprints [7]. That the training results obtained from the repetition sprint training program are in addition to an increase in anaerobic power and only a little aerobic power, an increase also occurs in fast muscle fibers and an increase in neoromuscular mechanics. Improving sprint and strength performance is beneficial for increasing muscle power output and athlete performance and is an important determinant of success in sports [8]

\subsection{Meter Running Characteristics}

The crowning of the 100-m sprint champion remains ahallmark of each Olympic Games, and the winners are "the world's fastest humans [9]. " The elements of the movement consist of: 1) limb movement, 2) arm movement, 3) posture, and 4) harmonious coordination of all the elements of the body movement. The 100-meter sprint fundamentally divided into different phases : the reaction phase at the start, the acceleration phase, the phase of maximum speed, the deceleration phase, and the finish [10]. All sprint distances from 100 meters to 400 meters are referred to as sprints or short distances. Short distance running is a running method in which the athlete must cover the entire distance or the distance traveled at the maximum possible speed or at full speed. In this sprint, running speed is a determining factor for achievement. The skill in running 100 meters is the ability to move the body position from one place to another quickly. The ability to resist fatigue and maintain the maximum intensity of activity

throughout the match or encounter has proven to be a very important ability for team sports athletes this ability is called repeated sprint ability (RSA) [11].

Running a 100 meter sprint requires components or elements of physical conditions, including reaction speed to start, speed strength to the first 30 meters, acceleration or acceleration from 30 meters to a distance of 80 meters, speed endurance in the last 20 meters. . The 100 meter run is basically the movement of the whole body forward as fast as possible which is produced by the movement of the footsteps over a distance of 100 meters, the main elements of which are the length of the stride and the speed of the frequency of the steps. The use of repeated sprint exercise for the training and testing of athletes has become more popular in recent years [12]. 


\section{Methods}

This research uses the pre-test and post-test design. The samples of this research were 15 students of the Sports Training Education Study Program at the Ganesha University of Education. These sample students are categorized as having high-level physical fitness. This category was the result of a physical fitness test in this research, which was done through a 2.4-kilometers run. The grouping was done randomly. After grouping, the 100-meter run pre-test was done, followed by experiment treatment. The treatment was conducted by applying the repetition sprint training method. It was conducted by doing the repeated sprint runs at a maximum speed, alternated with recovery periods.

\section{Results and Discussion}

The following is the interpretation of the results of data analysis.

The data analysis from paired sample T-test.

Table 1. The result description of the speed in 100-meter Run

\begin{tabular}{cccccc}
\hline Statistics & N & Minimum & Maximum & Mean & $\begin{array}{c}\text { Std. Devia- } \\
\text { tion }\end{array}$ \\
\hline Pree Test & 15 & 13,27 & 16,02 & 14,5820 &, 83339 \\
\hline Post Test & 15 & 12,03 & 15,01 & 13,4307 &, 90260 \\
\hline
\end{tabular}

Table 2. Reasearch Result Showing The difference between Pre-Test dan Post-Test Score

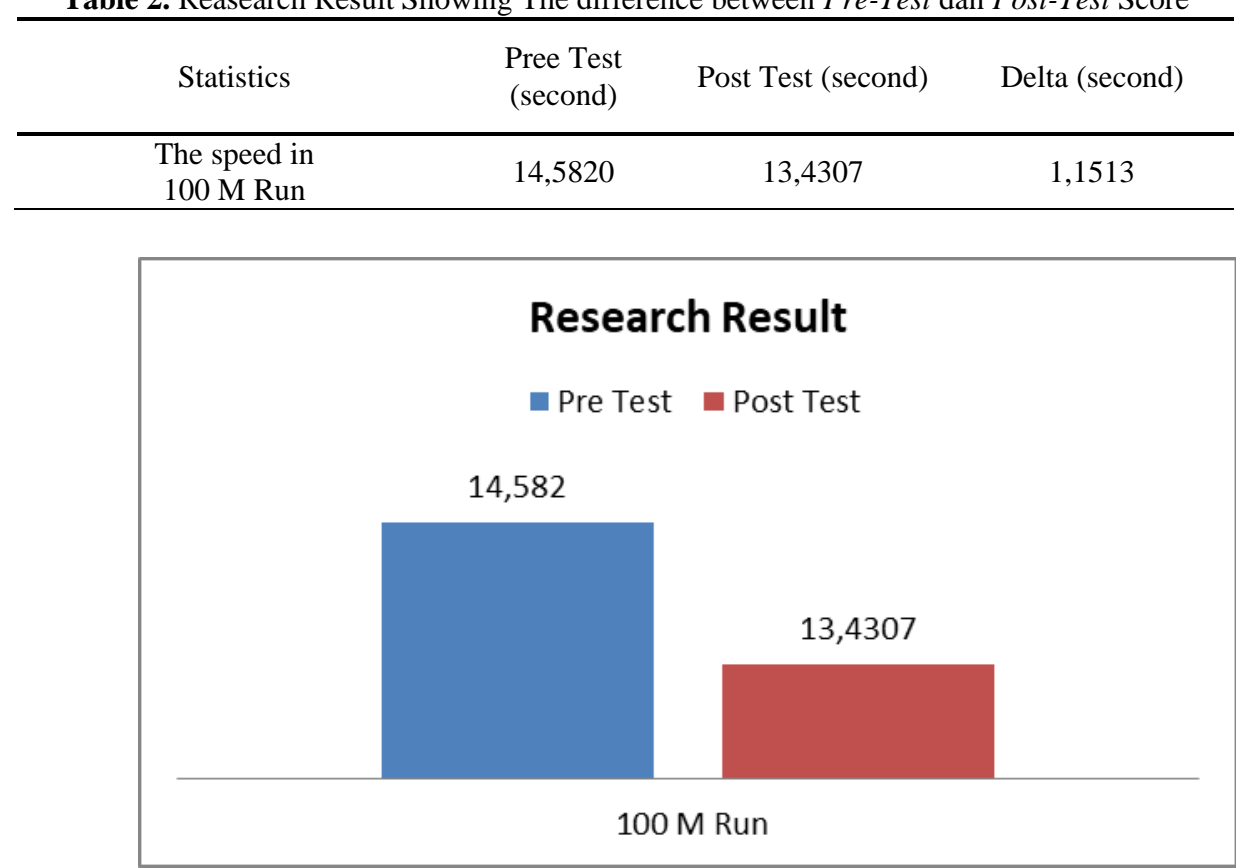

Fig 1. The difference of the speed in 100 meter run.

The data prerequisite normality test in this research was done before the T-test. The distribution normality test was done to find the scientific prove whether the research data has a normal distribution. The homogeneity test was not conducted since the research samples are categorized as homogeneous.

Table 3.The Data Distribution of Normality Test

\begin{tabular}{ccc}
\hline \multicolumn{3}{c}{ Tests of Normality } \\
\hline & Shapiro-Wilk & \\
\hline Group & Sig. & Description \\
\hline Pree Test & 0,400 & Normal \\
\hline Post Test & 0,781 & Normal \\
\hline
\end{tabular}

As mentioned in Table 3, the pre-test ad post-test scores have a normal distribution, as the significant value show $>0.05$. The result of the analysis of paired sample t-test was conducted to find out whether there is a significant effect after the treatment. After getting the result that the data was normal and homogenous, the parametric statistics test was conducted as the following step. 
Table 4. The Result of Paired Samples T-Test

\begin{tabular}{ccc}
\hline \multicolumn{3}{c}{ Paired Samples Test } \\
\hline & & Sig. (2-tailed) \\
\hline The speed of 100 M Run & Pree test - Post test & 0,000 \\
\hline
\end{tabular}

Based on Table 4, it can be seen that result of the speed analysis shows 0.000 or Sig, $<0.05$. It means that there is a significant effect of the sprint repetition training towards the speed in the 100-meter run.

Several methods can be applied to improve the run speed such as repetition, interval, or continuous method. This research uses repetition sprint to improve the run speed. Further, it is stated that each repetition should be done perfectly repetition sprint gives improvement mostly in anaerobic power instead of aerobic power. Moreover, it is mentioned that there is improvement in the fibers of the quick muscles and mechanic improvement in neuromuscular. However, this training has high injury risk, especially in foot muscles, because the acceleration of the 100-meter sprint run is done in a short time (10 - 15 seconds), also called cyclic sport as it uses an anaerobic energy source. The higher the speed, the more anaerobic energy source is needed [13]. In addition, speed is also influenced by several aspects, such as anaerobic endurance, strength, reaction time, and flexibility [14] In conclusion, it is important to maintain physical fitness during speed training in running. It can be stated that an athlete's physical fitness has an impact not only on his performance but also crucial in maintaining his physical capacity [15]. Physical fitness is one of the main aspects of sprint run achievement.

Physical fitness condition varies among individuals. Some have high physical fitness; some others are moderate to low. This condition influences someone's run speed. People with high physical fitness improves their run speed better compared to those with low physical fitness. They can also accelerate their movement speed, basic speed, and speed forbearance, compared to those with low physical fitness. When there is a need to improve sport achievement, physical fitness is essential in every sport, combined with the correct training method to improve speed. Also in reverse, speed improvement requires good physical fitness. These theories are supported by the result of data analysis in this research. The result shows an average acceleration of the speed in the 100-meter run among the students with high physical fitness is 456.1 points. According to [16], the speed in sprint run is the result of strong contraction among the muscles, which is transformed into smooth, fluent, efficient movement. This movement is essential to a sprint runner. At its core, it is important to choose a type of training in improving the sprint ability. This research reveals that the improvement in sprint run is affected not only by having a high physical fitness, but also the application of sprint repetition training method. Both variables in this research have an important function as they will be sharpened by the coach according to the data and the training program target goal.

\section{Conclusion}

Based on the result of the research, it can be concluded that the repetition sprint method done in 24 sets of treatment improves the capability in the 100-meter run. The average acceleration gained was 1.15 seconds from the whole 15 students sample. T-test result shows that there is a significant difference in the recorded time in the pre-test and post-test. As one of the main components in all sports, physical fitness can be built and maintain through effective training, which results in the ability to accelerate the speed in running. Reversibly, improving run's speed requires quality physical fitness.

This research's samples were students with a high level of physical fitness among their group. It is expected that future research is done by combining the same training method with two or three different levels of physical fitness. Another training method can also be tested to find out the comparison of the effectiveness among the available methods.

\section{References}

[1] E. Rudiansyah, Soekardi, and T. Hidayat, "Pembinaan Olahraga Prestasi Unggulan di Kabupaten Melawi Kalimatan Barat," J. Pendidik. Jasm. Kesehat. dan Rekreasi, vol. 4, no. 1, pp. 1-14, 2017.

[2] K. Sanborn, "Development of Explosive Power: Plyometric training.," Olympic Coach, vol. 20, no. 2, pp. 12-13, 2008, [Online]. Available: http://search.ebscohost.com/login.aspx?direct=true\&db=s3h\&AN=31930544\&amp\%0Alang=pt-br\&site=ehost-live.

[3] M. A. Almy and S. Sukadiyanto, "Perbedaan Pengaruh Circuit Training Dan Fartlek Training Terhadap Peningkatan Vo2Max Dan Indeks Massa Tubuh,” J. Keolahragaan, vol. 2, no. 1, pp. 59-68, 2014, doi: 10.21831/jk.v2i1.2603.

[4] I. G. N. Nala, "Prinsip Pelatihan Fisik Olahraga," Udayana University Press. 2011.

[5] R. Henjilito, M. Asmawi, J. Tangkudung, and A. T. Bon, "Model of skill sprint 100 meters, experiment study the method of exercise and reaction time on male students of physical education," Proc. Int. Conf. Ind. Eng. Oper. Manag., no. July, pp. 24952502, 2019.

[6] G. P. Paradisis, A. Bissas, and C. B. Cooke, "Effect of combined uphill-downhill sprint training on kinematics and maximum running speed in experienced sprinters," Int. J. Sport. Sci. Coach., vol. 10, no. 5, pp. 887-897, 2015, doi: 10.1260/17479541.10.5.887.

[7] R. G. Lockie, A. J. Murphy, A. B. Schultz, T. J. Knight, and X. A. K. J. De Jonge, "The effects of different speed training protocols on sprint acceleration kinematics and muscle strength and power in field sport athletes," J. Strength Cond. Res., vol. 26, no. 6, pp. 1539-1550, 2012, doi: 10.1519/JSC.0b013e318234e8a0.

[8] E. Sáez de Villarreal, B. Requena, M. Izquierdo, and J. J. Gonzalez-Badillo, "Enhancing sprint and strength performance: Combined versus maximal power, traditional heavy-resistance and plyometric training," J. Sci. Med. Sport, vol. 16, no. 2, pp. 146150, 2013, doi: 10.1016/j.jsams.2012.05.007.

[9] T. Haugen, S. Seiler, Ø. Sandbakk, and E. Tønnessen, "The Training and Development of Elite Sprint Performance: an Integration of Scientific and Best Practice Literature," Sport. Med. - Open, vol. 5, no. 1, 2019, doi: 10.1186/s40798-019-0221-0. 
[10] R. Wibowo, "the Impact of Assisted Sprinting Training (As) and Resisted Sprinting Training (Rs) in Repetition Method on Improving Sprint Acceleration Capabilities,” J. Pendidik. Jasm. Dan Olahraga, vol. 2, no. 1, p. 79, 2017, doi: 10.17509/jpjo.v2i1.7971.

[11] P. Performance, "Physical Performance," Phys. Act. Heal. Elder., pp. 31-36, 2012, doi: 10.2174/978160805100711001010031.

[12] S. K. Eryilmaz, Z. Aslankeser, Ç. Özdemir, K. Özgünen, and S. Kurdak, "The effect of 30-m repeated sprint exercise on muscle damage indicators, serum insulin-like growth factor-I and cortisol," Biomed. Hum. Kinet., vol. 11, no. 1, pp. 151-157, 2019, doi: 10.2478/bhk-2019-0021.

[13] T. Bompa and C. Buzzichelli, Periodization Training for Sports-3rd Edition. 2015.

[14] Harsono, "LATIHAN KONDISI FISIK OLAH RAGA-Prof Drs Harsono.pdf." 2001.

[15] A. Penelitian, "Kondisi Atlet Panahan Program Atlet Andalan Nasional Indonesia Emas (Prima)," Media Ilmu Keolahragaan Indones., vol. 1, no. 1, 2011, doi: 10.15294/miki.v1i1.1132.

[16] I. Siswantara et al., "Sport Science:," pp. 83-90. 